\title{
FALASIFA
}

Peran Penyuluh Agama Terhadap Kerukunan Antar Umat Beragama

\section{PERAN PENYULUH AGAMA TERHADAP KERUKUNAN ANTAR UMAT BERAGAMA DI DESA SUKORENO KECAMATAN UMBULSARI KABUPATEN \\ JEMBER}

\author{
Mahbub Junaidi \\ Universitas Islam Negeri Sunan Kalijaga Yogyakarta \\ Email.mahbuubjunaidi@gmail.com
}

\begin{abstract}
This study was written to see the village of Sukoreno, Mumbulsari District, Jember Regency, which has the characteristics of biodiversity diversity. The population consists of followers of Islam, Christianity, Hinduism and Hindu culture. This study seeks to examine tolerance in inter-religious relations in the village of Sukoreno Umbulsari, the extent to which harmony between religious communities and how the role of religious extension agents are in caring for and maintaining religious harmony in Sukoreno. This research uses qualitative research methods field research (field reaserch). Community in Sukerone village Umbulsari sub-district is a community consisting of many different ethnicities, cultures, traditions and even traditions, but the attitude of mutual respect, giving freedom of religion, accepting other religions gracefully, and always having a positive attitude between religions. Religious extension workers, as an extension of the government, continue to carry out their duties, from providing counseling to advocating for religious issues to improve the quality of harmony between religious communities.
\end{abstract}

Keywords: Religious Counselor, Inter-Religious Harmony, Sukoreno Umbulsari

\begin{abstract}
ABSTRAK
Penelitian ini ditulis melihat desa Sukoreno kecamatan Mumbulsari Kebupaten jember memiliki ciri keanekaragaman keagamaan. Penduduknya terdiri dari pemeluk agama Islam, Kristen, Hindu, hindu budaya. Penelitian ini berupaya untuk mengkaji toleransi dalam hubungan antar umat beragama di desa Sukoreno Umbulsari, sejauh mana harmunisi dan kerunan antar umat bergama serta bagaimana peran penyuluh agama untuk merawat dan menjaga kerukunan umat beragama di Sukoreno. Penelitian ini menggunakan metode penelitian kualitatif jenis penelitian lapangan (field reaserch). Masyarakat Di desa Sukerone kecamatan Umbulsari adalah masyarakat yang majemuk dimana terdiri dari dari banyak etnis, budaya, tradisi bahkan tradisi yang berbeda. Tetepi sikap saling menghormati, memberikan kebebasan beragama, menerima agama lain dengan lapang dada, dan selalu saling berfikri positif antar pemeluk agama. Penyuluh agama sebagai kepanjangan tangan dari pemerintah terus melakukan tugasnya mulai dari melakukan penyuluhan sampai
\end{abstract}


mengadvokasi permasalahan-permasalahan keberagamaan upaya meningkatkan kualitas kerukunan antar umat beragama.

Kata Kunci: Penyuluh Agama, Kerukunan Antar Umat Beragama, Sukoreno Umbulsar

\section{PENDAHULUAN}

Indonesia lahir dengan Kebhinnekaan etnis, suku, bahasa, agama dan budaya. Dimana bhinnika tunggal ika menjadi semboyan bangsa Indonesia sebagaimana tercantum dalam lambang Burung Garuda Pancasila, di kaki Burung Garuda terlihat sangat jelas tulisan Bhinneka Tunggal Ika. Hal ini menjadi jelas bahwa Indonesia terlahir dengan kebhinnekaannya sehingga kita harus menjaga dan melestarikan kekayaaan Indonesia ini.

Meskipun dengan keanekaragaman yang dimiliki indonesia ini, tidak kemudian mabawa kedalam negara yang penuh dengan konflik tetapi justru menjadikan Indonesia sebagai negara yang kuat dan kaya. Seperti yang kita tau Keanekaragaman di Indonesia terdapat dalam banyak elemen yakni misal banyaknya suku, budaya, etnis, bahasa serta agama. Tetapi yang paling menarik yang selalu dibahas oleh para cendikiawan yakni persoalan-persoalan seputar agama, karena pembahasan agama akan menjadi sangat senistif di semua kalangan. Hal ini terjadi karena banyaknya Agama yang ada di indonesia seperti yang kita tahu ada agama Islam, Protestan, Katolik, Hindu, Buddha serta Konghucu dimana ke enam agama ini diakui dan disahkan di negara indonesia artinya setiap warga indonesia diberikan kebebasan untuk bergama sesuai dengan keyakinannya masing-masing.

Bila kita renungkan dan kita nalar dengan akal manusia, tentu hal ini akan terus

menyeret bangsa kita terhadap persoalan-keagamaan dan akan mengganggu terhadap harmunisasi kerukunan masyarakat indonesia, karena setiap agama mempunyai kepercayaan tersendiri, mempunyai kitab dan aturan tersendiri, yang tentu terdapat perbedaan antar satu agama dengan agama yang lainnya.

Agama dapat berperan fungsi konstruktif dan destruktif. Dimana secara konstruktif ikatan agama akan melampaui ikatan hubungan nasab serta keturunan. Maka banyak karena ikatan agama yang sama para penganutnya berbondong bondong membentuk komunitaskomunitas keagamaan atau kalau di indonesia disebut ormas (oranisasi masyarakat) yang 
berpedoman terhadap agamanya masing-masing dan menjadi saudara yang melampaui ikatan darah. Tetapi secara destruktif kekuatan agama sangat memungkinkan untuk merusak harmunisasi antar umat beragama bahkan memutus ikatan daran, nasab dan keturnan lantaran konflik-konfilk keagamaan. ${ }^{1}$ dimana jikan ada konflik agama antar pemeluknya ini, maka akan mengganggu keharmunisan antar pemeluknya dan sangat merugikan bangsa dan negara, karena konflik ini akan berakibat terhadap berbagai aspek kehidupan.

Sementara kondisi umat beragama akhir-akhir ini cendrung tidak lagi sebagai kekuatan mencapai kedamaian melainkan menjadi sesuatu yang menakutkan dimana hal ini dapat dilihat dengan adanya praktek-praktek kekerasan yang difaktori dengan pemahaman keagamaan yang varian dan mengarah pada sikap fanatik terhadap golongan tertentu. Padahal pada subtansinya dari Agama-Agama mengajarkan kedamaian misalkan dalam islam di sebutkan dalam Al-Qur'an Surat Al-hujarat/49 Ayat 13:

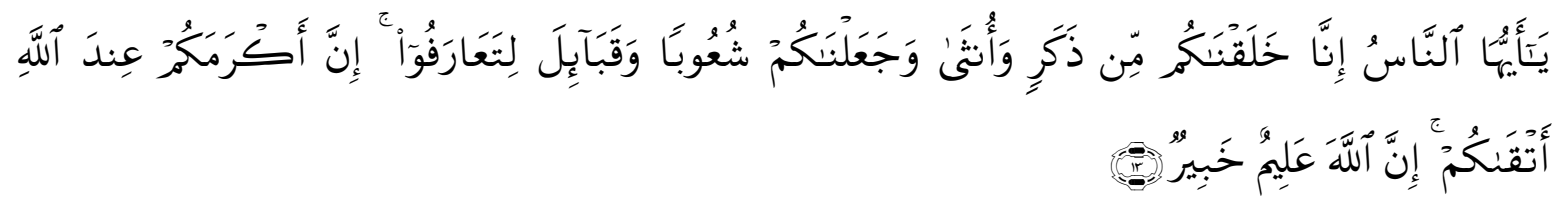

Artinya: Hai manusia, Sesungguhnya Kami menciptakan kamu dari seorang lakilaki dan seorang perempuan dan menjadikan kamu berbangsa - bangsa dan bersuku-suku supaya kamu saling kenal-mengenal. Sesungguhnya orang yang paling mulia diantara kamu disisi Allah ialah orang yang paling taqwa diantara kamu. Sesungguhnya Allah Maha mengetahui lagi Maha Mengenal. (Al-hujarat/49 Ayat 13)

Dalam Agama Kristen juga banyak mengajarkan tentang kedamaian dan kerukunan sebagaimana di ungkapkan dalam kitab Matius, 5: 5-9:

Berbahagialah orang-orang yang lembut karena mereka akan memiliki bumi. Berbahagialah orang-orang yang lapar dan haus akan kebenaran karena mereka akan dipuaskan. Berbahagilah orang yang murah hatinya karena mereka akan beroleh kemurahan. Berbahagilah orang yang suci hatinya karena mereka akan melihat Allah.

\footnotetext{
${ }^{1}$ Joachim Wach, The Comparative Study of Religions (New York: Columbia University Press, 1958), 128.
} 
Berbahgialah orang yang membawa damai karena mereka akan disebut anak Allah (Matius, 5: 5-9)

Dalam agama Hindu juga sangat kental mengajarkan tentang kerukunan umat beragama sebagaimana dalam dijelaskan statemen dalam Kitab Regweda yang berbunyi "Ekan Sat Vipra Bahuda Vadanti " yang artinya disebut dengan ribuan nama berbeda namun satu adanya. Statemen dalam kitab ini tak ubahnya seperti semboyan Bhinneka Tunggal Ika yang artinya berbeda-beda tapi satu.

Dalam Agama Buddha juga mempunyai pandangan terkait kerukunan hidup umat bergama yang didasarkan kepada empat kebenaran, yaitu dhuha satya, samudaya satya, tanha dan marga satya. Sehingga dari dasar inilah Dari dasar ini, maka kehidupan Buddha terhadap manusia dilaksanakan dengan dasar Keyakinan terhadap Tuhan yang dapat dicapai dengan pikiran manusia, Metta, welas asih terhadap semua makhluk, Karuni yakni kasih sayang kepada sesama dan membantu meringakan, Mudita, merakan bahagian kepada makhluk atau manusia yeng mendapat kenahagiaan, dan Karma, hukum sebab akibat.

Sedangkan dalam Agama Khonghucu yakni agama baru yang diresmikan Gussur di Indonesia, Agama Konghucu ini juga mengajarkan toleransi, dimana menjadi prinsip dasar dari ajaran Agama Khongucu sebgaimana di sebutkan dalam Kitab (Tengah Sempurna, XII: 3) "jangan lakukan kepada orang lain apa yang tidak ingin engkau terima oleh orang lain". Selain itu, dinyatakan oleh Nabi Konghucu bahwa "Seorang budiman berhati longgar dan lapang, seorang rendah budi berhati sempit dan berbelit" hal ini di sebutkan dalam Sabda Suci, VII: 37. Jadi bisa dilhat agama yang baru diresmikan di indenesia pun juga mempunyai prinsip-prinsip tentang kerukunan antar umat beragama. Sehingga padaha hakikatnya setia agama agama yang ada di Indonesia pada subtansinya mengajarkan nila-nilai kerukunan dan harmunisasi antar umat beragama.

Umbul sari merupakan salah satu kecamatan di jember yang memiliki beberapa desa yakni desa Sukoreno, Gunungsari, Umbulsari, Tanjungsari, Tegalwangi, Paleran, Umbulrejo, Gadingrejo, Sidorejo dan Mundurejo. ${ }^{2}$ Dari Sepuluh desa ini, desa Sukoreno

\footnotetext{
${ }^{2}$ Umbusari dalam Angka 2020 (Jember: BPS Kabupaten Jember)
} 
menjadi satu yang paling menarik perhatian dari pada desa yang lain, karena didesa ini dikenal dengan desa pancasila terdiri dari banyak kedudayaan dan agama yang berbedabeda tetapi mampu hidup berdampingan di desa sukerono ini. Berdasarkan data statistik kecamatan umbulsari penduduk desa ini memeluk agama yang berbeda-beda mulai dari agama Islam, Protestan, Katolik, Hindu, Budha hanya saja tidak ada penduduk Sukoreno yang menganut agama Konghucu. Jumlah penduduk agama islam menjadi mayoritas, tetapi bukan tetapi bukan berrti meninggal dan menindas yang mino ritas melain mampu hidup rukun dan berdampingan. ${ }^{3}$

Penyuluh agama menjadi salah satu yang beperan penting dalam menjaga kerukunnan antar umat beragama karena penyuluh agama disiapkan oleh pemerintah untuk menjadi benteng pertahanan dari konflik-konflik keagamaan yang terjadi di masyarakat. Oleh karenanya, berdasarkan uraian latar belakang di atas peneliti mengambil judul penelitian "Peran Penyuluh Agama Terhadap Kerukunan Antar Umat Beragama Di Desa Sukoreno Kecamatan Umbulsari Kabupaten Jember”.

\section{METODE PENELITIAN}

Penelitian ini menggunakan metode penelitian kualitatif jenis penelitian lapangan (field reaserch). Tujuan penelitian menggunakan jenis penelitian ini tentu bertujuan untuk memudahkan penelitian yang akan di gunakan dilapangan. Dengan teknik pengumpulan data menggunakan teknik wawancara, Observasi, dan Dokumentasi.

\section{PEMBAHASAN}

\section{A. Kerukunan Umat Beragama}

Pengertian kerukunan berasal dari kata "rukun" dimana rukun dalam Kamus Bahasa Indonesia bermakna baik, damai, tidak bertengkar, perkumpulan saling tolong menolong dan persahabatan. Kerukunnan itu sendiri berarti berdiri dari beberapa perbedaan dan sama sama memberikan kekuatan bukan untuk melemahkan antar saru dan yang lainnya. Sedangkan pengertian kerukunan secara luas yakni berarti persaudaraan dan kebersamaan dengan semua orang yang berbada etnis, suku, ras,

\footnotetext{
${ }^{3}$ Umbusari dalam Angka 2020 (Jember: BPS Kabupaten Jember)
} 
agama dan budanya. ${ }^{4}$ Rukun dalam bahasa Indonesia juga memiliki arti, cocok, selaras, sehati, tidak berselisih. Sehingga untuk mendapatkan kerukunan yang seutuhnya membutuhkan keselarasan, kecocokan dan damai tanpa konflik atau perselisihan. Menerima perbedaan dengan dengan terbuka artinya tidak memahami kebenaran hanya dari keyakinannya sendiri, misalkan penganut agama islam hanya membenarkan dirinya dan orang lain dianggap salah karena tidak menganut agama islam, sebaliknya dengan agama agama yang lain. Pemahaman seperti ini menumbuhkan benih benih perselisihan antar perbedaan.

Kerukunan umat beragama dalam Peraturan bersama Mentri Agama dan Menteri Dalam No. 9 dan 8 Tahun 2006 tentang Pedoman Pelaksanaan tugas Kepala Daerah/ Wakil Kepala Daerah dalam pemeliharaan kerukunan umat beragama, pemberdayaan forum kerukunan umat beragama, dan pendirian rumah ibadat pasal 1 angka (1) disebutkan bahwa: Kerukunan umat beragama adalah keadaan hubungan sesama umat beragama yang dilandasi toleransi, saling pengertian, saling menghormati, menghargai kesetaraan dalam pengamalan ajaran agamanya dan kerjasama dalam kehidupan bermasyarakat, berbangsa dan bernegara di dalam Negara Kesatuan Republik Indonesia berdasarkan Pancasila dan Undang-Undang Dasar Negara Republik Indonesia Tahun 1945. Bila dilihat dan mencermati Peraturan bersama di atas nampaknya memberikan pengertian bahwa kerukuna umat beragama tidak hanya diberikan pengertian kerukunan secara batiniah tetapi juga bagaimana antar agama ini mampu bekerjasama dalam setiap hal.

Pengertian Kerukunan menurut W. J.S Purwadarminta yaitu sikap atau sifat menenggang yang menghargai dan membebaskan suatu pendirian, pandangan, pendapat, kepercayaan yang berbeda dengan diri sendiri. ${ }^{5}$ Sedangkan menurut Dewan Ensklopedi Indonesia pengertian Kerukunan dalam aspek sosial, politik, merupakan suatu sikap memberikan kebebasan terhadap keyakinan yang berbeda. juga menerima pendapat ini

\footnotetext{
${ }^{4}$ Saidurrahman dan Arifinsyah. Nalar Kerukunan: Merawat Keragaman Bangsa Mengawal NKRI (Jakarta: PT. Prenadamedia Group, 2018), 17

${ }^{5}$ W.J.S Porwadarminta, kamus Umum Bahasa Indonesia(Jakarta, Balai Pustaka1986) 1084
} 


\section{Mahbub Junaidi}

atas dasar menghormati hak asasi manusia. ${ }^{6}$ Dan juga menurut Ensiklopedi Amerika Kerukunan memiliki Arti yang sangat terbatas. Dimana berkonotasi menahan diri dari pelanggaran dan penganiayaan, meskipun memperlihatkan sikap tidak setuju yang tersembunyi tetapi tindakan yang diambil sangat terbatas oleh kebebasan syarat-syarat tertentu. ${ }^{7}$

H. Said Agil Husain memberikan arti terkait kerukunan dalam bukunya yang berjudul "Fikih Hubungan Antar Agama" mendefinisikan kerukunan Kerukunan ditandai dengan adanya lingkungan persaudaraan dan kebersamaan antara semua orang dengan latar belakang ras, etnis, suku, budaya dan agama yang berbeda. ${ }^{8}$ Jadi jelas bahwa kerukunan itu tidak memandang dari latar belakang perseorangan yang berbeda dengan dirinya. Jika hanya dengan internal yang sama dengan dirinya maka tidak namakan kerukunan melainkan fanatisme golongan.

Pemerintah dalam terminologi resminya merinci kerukunan menjadi 3 (Tiga) bagian, yakni; 1. kerukunan intern umat dalam satu agama masing masing. Dimana disetiap agama tentunya memiliki aliran yang berbeda-beda sehingga antar aliran dalam satu rumpun agama bisa hidup rukun dan berdampingan. Misalnya dalam islam ada beberpa alira seperti Ahlussunnah, Syi'ah, Murji'ah Khowarij dan lain lain yang kemudian rijid hinggan menjadi ormas yang berbeda pula. Terkadang mesikipun menggunakan paham yang sama tetapi juga memunculkan organisasi keagamaan yang berbeda, katakana MUHAMMADIYAH dan NU, ia sama-sama menggunaham Ahlussunnah Wal Jama'ah tetapi mempunyai pemahaman dan penafsiran dalam hal-hal tertentu. 2. Kerukunan antar umat beragama yang berbeda-beda. Yakni rukun antar pemeluk agama yang berbeda, antara pemeluk agama islam dengan pemeluk agama Kristen, hindu budha dan konghucu. Jadi rukun meskipun keyakinan agamanya berbeda dengan dirinya. 3. Kerukunan antara umat beragama dengan birokrasi/pemerintah.

\footnotetext{
${ }^{6}$ Dewan Ensiklopedi Indonesia, Ensiklopedia Indonesia Jilid 6,(Van Hoeve,t,th), 3588

${ }^{7}$ Dewan Ensiklopde American, Ensiklopedi American

${ }^{8}$ H. Said Agil Husain Al Munawar. Fikih Hubungan Antar Agama(Jakarta,Ciputat Press. 2003), 4
} 
Yakni untuk tetap menjaga keseimbangan dang keutuhan NKRI maka perlu hidup rukun antara komunitas keagamaan dengan pemerintah sebagai agen manajeman kenegaraan. ${ }^{9}$

Untuk meningkatkan kualitas kerukunan ummat beragama, setidaknya ada lima hal untuk terus dikembangkan yaitu:

1. Nilai Religius. Yakni kerukuan ummat beragama yang dibangun setidak merepresentasikan sikap yang religious artinya terbangun dari ketulusan pengabdian diri terhadap tuhannya. Jadi kerukunan umat yang di bangun murni karena mutif diri untuk mendapat keridhoan, keselamatan dan kesejahteraan dari tuhannya.

2. Keharmonisan. Kerukunan ummat beragama akan terlihat bila mana antar umat beragama melakukan hubungan yang harmonis.

3. Kedinamisan. Yakni kualitas kerukunan umat beragama juga dilihat bagaimana antar umat beragama mampu meperlihatkan suaasna yang dinamik, bersemangat, bergerak dan mudah menyesuaikan diri dengan keadaan yang ada.

4. Kreaativitas. Yakni kerukunan di orientasikan kreatif upaya pengembangan bersama antar agama

5. Produktif. Yakni kerukunan ini diarahkan kepada suatu yang bermanfaat kepada banyak orang missal gotong royong, membantu yang miskin, bakti sosial dan lain sebagainya. $^{10}$

Untuk menjalankan interaksi kerukunan umat beragama maka menurut Hamzah

Tualeka Zn harus menjalankan sebagai berikut:

1. Saling menghormati. Setriap umat beragama harus saling menghormati antara agama dengan agama yang lain dengan cara tidak mencaci maki dan mencari kejelekankejelekan agama lain, karena hal ini akan menjadi perselisihan antar umat beragama.

2. Kebebasan Beragama. Kebebasan Bergama sesuai keyakinannya ini terdapat dalam semua agama, dimana tidak ada pemaksan dalam agama. Selain factor petunjuk dari

\footnotetext{
${ }^{9}$ Depag RI. Bingkai Teologi Kerukunan Hidup Umat Beragama Di Indonesia,(Jakarta: Badan Penelitian dan pengembangan Agama Proyek Peningkatan KUB di Indonesia. 1997), 8-10

${ }^{10}$ Ridwan Lubis. Cetak Biru Peran Agama (Jakarta, Puslitbang, 2005), 12-13
} 
tuhannya, Factor lingkungan dan keturunan juga sangat berpengaruh terhadap agama yang akan diikuti.

3. Menerima dengan apa adanya. Setiap orang harus mampu meneriman kekurangan dan kelebihan agama lain serta mampu menerima keberadaan agama selain agama yang diikutinya. Misalkan agama Kristen menerima kehadiran agama Islam sebaliknya Islam juga menerima dengan adanya agama Kristen.

4. Berfikir positif (Khusnu Dzon). Berbaik sangka pada agama dan orang lain menjadi hal yang sangat penting terhadap kerukunan umat beragama. ${ }^{11}$

Masyarakat Di desa Sukerone kecamatan Umbulsari adalah masyarakat yang majemuk dimana terdiri dari dari banyak etnis, budaya, tradisi bahkan tradisi yang berbeda. Tetepi sikap saling menghormati, memberikan kebebasan beragama, menerima agama lain dengan lapang dada, dan selalu saling berfikri positif antar pemeluk agama tetap erat menjadi karakter masyarakat sukoreno bahkan sampai dekenal dengan desa pancasila dikabupaten jember. kondisi lingkungan yang terjadi yang terjadi dilingkungan desa sukoreno ini sangat mencerminkan sikap rukun antar umat beragama. ${ }^{12}$

\section{B. Krukunan Umat Berama Perspektif Agama-Agama}

Seperti yang kita ketehui ada beberapa agama yang di akui secara sah di negara Indonesia yaitu Agama Islam, Kristen Protestan, Kristen Katolik, Hindu, Budha dan Konghucu. Dimana masing masing agama ini mempunyai kitab masing-masing. Agama Islam mempunyai Kitab Al-Qur'an sebagai pedoman hidupnya, agama Kristen dengan kitab sucinya al-kitab atau "Bibel" , agama Hindu kitab Weda sebagai kitab sucinya, , agama Buddha kitab "Tripitaka" sebagai kitab sucinya, dan Konghuchu dengan kitab "Susi" sebagai kitab sucinya.

Dimana kitab suci tersebut menjadi pedoman bagi pemeluknya baik pedoman hubungan vertical maupun horizontal. Masing-masing dari kitab suci agama-agama itu banyak membicarakan tentang hubungan horizontal, hubungan antar manusia sampai

\footnotetext{
${ }^{11}$ Hamzah Tualeka Zn. Sosiologi Agama (Surabaya: UINSA Press, 2011), 156-161

${ }^{12}$ Syamsul Huda, Wawawncara, Penyuluh Agama Umbulsari. 10 Desember
} 
hubungan atau kerukunan umat beragama. Selaras dengan yang disampaikan Syahrin Harahap berpendapat bahwa jika umat beragama benar-benar mempelajari kitab suci yang dipercayainya maka pasti akan mengetahui bahwa kitab sucinya mengajarkan tentang kerukunan umat beragama. ${ }^{13}$ Kerukunan umat beragama pespektif agama-agama yaitu sebagai berikut:

1. Kerukunan Umat Beragama Perspektif Agama Islam

Lahirnya islam di indonesia tidak dengan aksi aksi kekerasan, tidak satupun sejarah mencatat bahwa islam saat melakukan ekpansi diindonesia dilakukan dengan pertumpahan darah. Sejarah mencatat bahwa masuknya Indonesia melalui perdagangan dan perkawinan hal itu sebagaiamana kita ketahui dengan teori Persia, Gujarat dan mekkah. Oleh karenanya kontruksi sikap pemeluk agama islam di Indonesia selain karena faktir ajarannya toleran, juga difaktori dengan sejarah masukknya Islam di Indonesia yang sangat ramah tanpa pertumpahan darah.

Kemajemakan dalam islam itu sendiri sebenarnya menjadi hal yang niscaya dan tidak patut dipertentangkan, karena ini dipandagang sebagai rahmat Allah SWT. Sebagaimana dijelaskan secara gamblang dalam Al-Qura'an:

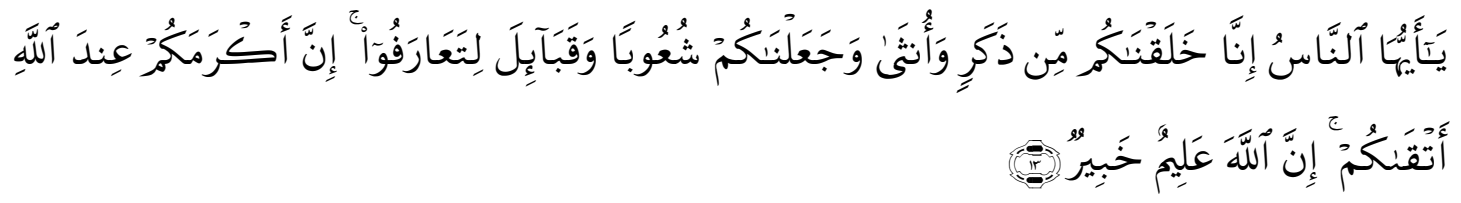

Artinya: Hai manusia, Sesungguhnya Kami menciptakan kamu dari seorang laki-laki dan seorang perempuan dan menjadikan kamu berbangsa - bangsa dan bersuku-suku supaya kamu saling kenal-mengenal. Sesungguhnya orang yang paling mulia diantara kamu disisi Allah ialah orang yang paling taqwa diantara kamu. Sesungguhnya Allah Maha mengetahui lagi Maha Mengenal. (QS. Al-Hujurat/49 ayat 13$)$.

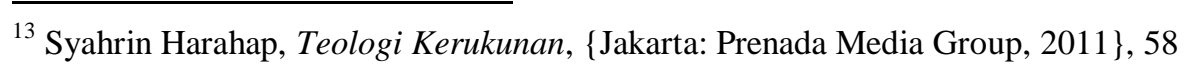

37 | Falasifa, Vol. 12 Nomor 1 Maret 2021 


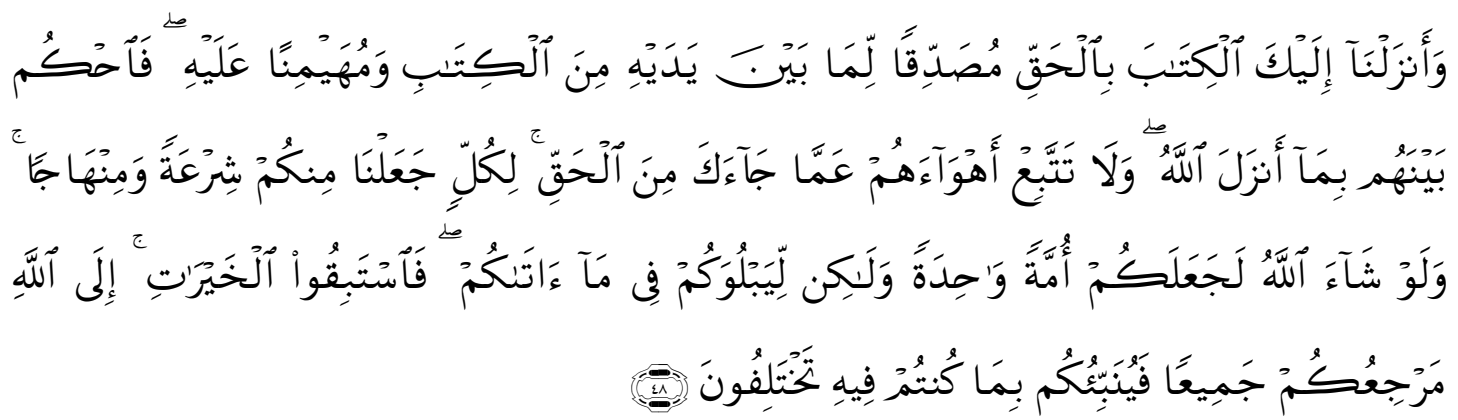

Artinya: dan Kami telah turunkan kepadamu Al Quran dengan membawa kebenaran, membenarkan apa yang sebelumnya, Yaitu Kitab-Kitab (yang diturunkan sebelumnya) dan batu ujian terhadap Kitab-Kitab yang lain itu; Maka putuskanlah perkara mereka menurut apa yang Allah turunkan dan janganlah kamu mengikuti hawa nafsu mereka dengan meninggalkan kebenaran yang telah datang kepadamu. untuk tiap-tiap umat diantara kamu. Kami berikan aturan dan jalan yang terang. Sekiranya Allah menghendaki, niscaya kamu dijadikan-Nya satu umat (saja), tetapi Allah hendak menguji kamu terhadap pemberian-Nya kepadamu, Maka berlombalombalah berbuat kebajikan. hanya kepada Allah-lah kembali kamu semuanya, lalu diberitahukan-Nya kepadamu apa yang telah kamu perselisihkan itu, (Qs. AlMai'dah/5 Ayat 48)

Dalam Islam juga melarang pemeluknya untuk mencela, mengolok-olok, bahkan mencaci maki kepada pemeluk agama lain karena hal itu tidak mencerminkan Agama islam yang ramah dan Rahmatan Lil Alamin. Larangan tersebut bisa kita lihat dalam Al-Qura'an:

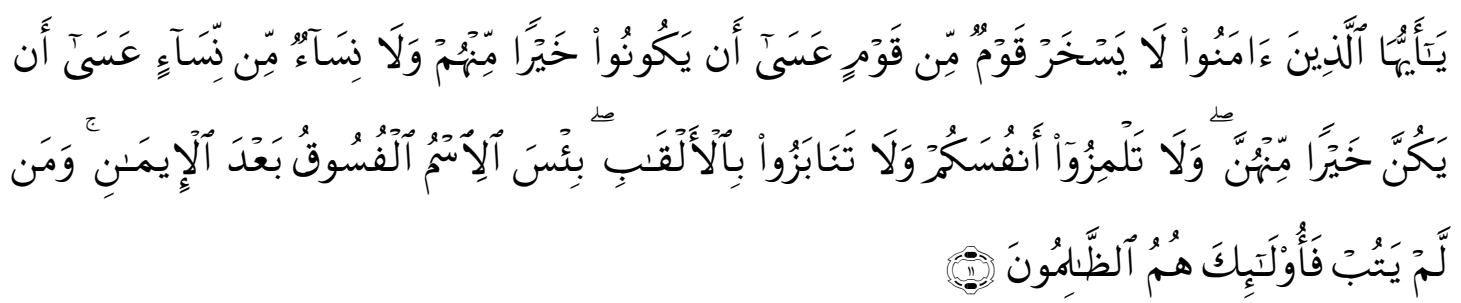

Artinya: Hai orang-orang yang beriman, janganlah sekumpulan orang lakilaki merendahkan (mengolok-olokan) kumpulan yang lain, boleh Jadi yang ditertawakan itu lebih baik dari mereka. dan jangan pula sekumpulan perempuan 
merendahkan kumpulan lainnya, boleh Jadi yang direndahkan itu lebih baik. dan janganlah suka mencela dirimu sendiri[1409] dan jangan memanggil dengan gelaran yang mengandung ejekan. seburuk-buruk panggilan adalah (panggilan) yang buruk sesudah iman[1410] dan Barangsiapa yang tidak bertobat, Maka mereka Itulah orang-orang yang zalim.(Qs. Al-Hujarat/49 ayat 11)

Sekalipun berbeda keyakinan sebagaimana disebutkan ayat di atas umat islam dilarang untuk mengolok-olok dan mencaci kepada mereka yang berbeda keyakinan. Dan dalam Islam pun kita dilarang untuk melakukan paksaan kepada pemeluk agama untuk memeluk agama islam. Sebagaimana di jelaskan dalam AlQur'an:

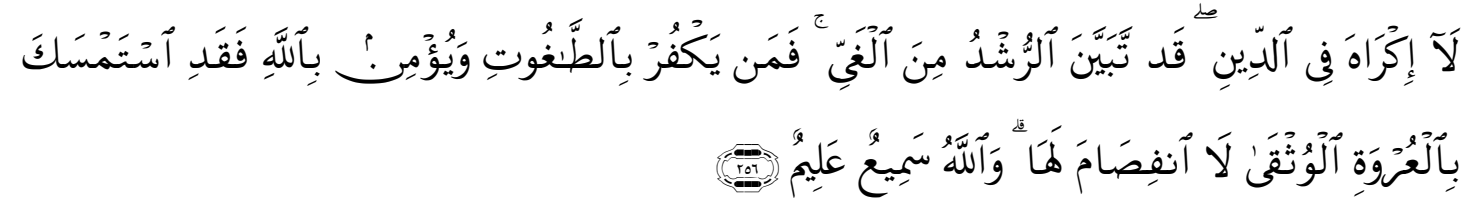

Artinya: Tidak ada paksaan untuk (memasuki) agama (Islam); Sesungguhnya telah jelas jalan yang benar daripada jalan yang sesat. karena itu Barangsiapa yang ingkar kepada Thaghut dan beriman kepada Allah, Maka Sesungguhnya ia telah berpegang kepada buhul tali yang Amat kuat yang tidak akan putus. dan Allah Maha mendengar lagi Maha mengetahui. (QS. Al-Baqarah/2 ayat 256)

Sayyid Qutb dalam kitab tafsirnya Fi Zhilalil Qur'an memberikan memnerikan penjelesan terkait tafsir ayat di atas yakni persoalan Aqidah itu adalah persoalan kerelaan hati setelah mendapat keterangan dan penjelasan, bukan setelah dipaksa dan ditekan. Dalam Tafsir Al-Thabroni menjelaskan riwayat turunnya ayat ini yaitu ketika kelompok Yahudi yang diusir dari Madinah karena menyalahi perjanjian, ada anak-anak kaum Anshar di antara mereka. Kemudian Kaum Yahudi mengatakan kami tidak akan menyeru anak-anak kami untuk masuk Islam. Maka kemudian turunlah ayat di atas. Kemudian dikatanan kepada mereka: "Yang mau 


\section{Mahbub Junaidi}

tinggal menetap di Madinah (memeluk Islam), tinggal-lah di sini, bagi yang mau pergi (bergabung dengan orang Yahudi), maka pergilah. ${ }^{14}$

Dalam Islam dengan tegas dan jelas menjelasjan bahwa manusia telah diberikan kebebasan dalam memilih agama yang mereka yakini untuk dijadikan pedoman hidupnya. Namun masing-masing mereka akan bertanggung jawab dihadapan Allah SWT. Karena Allah lah yang akan memberikan keputusan dan Allah Akan memutuskannya dengan adil. Hal ini dijelaskan dalam firman-Nya:

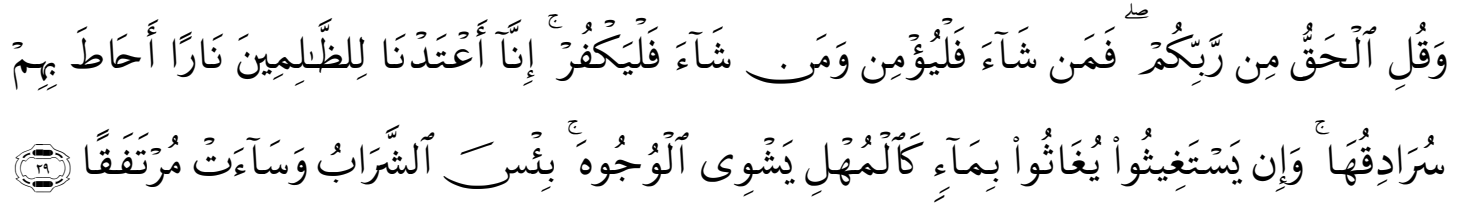

Artinya: Dan Katakanlah: "Kebenaran itu datangnya dari Tuhanmu; Maka Barangsiapa yang ingin (beriman) hendaklah ia beriman, dan Barangsiapa yang ingin (kafir) Biarlah ia kafir". Sesungguhnya Kami telah sediakan bagi orang orang zalim itu neraka, yang gejolaknya mengepung mereka. dan jika mereka meminta minum, niscaya mereka akan diberi minum dengan air seperti besi yang mendidih yang menghanguskan muka. Itulah minuman yang paling buruk dan tempat istirahat yang paling jelek. (Qs. Al-Kahfi/18 ayat 29).

Jadi dari beberap uraian dari Nas Al-qur'an diatas bahwah kemajemukan, perbedaan pendaan pendapat dan keyakinan keagamaan bukan menjadi alasan bagi umat muslim untuk mencela yang berbeda keyakinan dengannya melainkan sebagai ajang untuk saling menghormati dan saling merhargai antar satu dan yang lainnya, karena sesungguhnya hal itu adalah bagian dari kehendak Allah SWT.

\section{Kerukunan Umat Beragama Perspektif Agama Kristen}

Agama Kristen merupakan agama terbesar kedua setelah agama islam di Indonesia temasuk juga pemeluk agama di desa sukerone kecamatan umbulsari

\footnotetext{
${ }^{14}$ https://islam.nu.or.id/post/read/75972/tafsir-ayat--tidak-ada-pemaksaan-memeluk-islam-di akses pada tanggal 10 Desember 2020 Jam 09.00WIB
} 
Peran Penyuluh Agama Terhadap Kerukunan Antar Umat Beragama

kabupaten jember. ${ }^{15}$ Konsep kerukunan umat beragama dalam agama Kristen yang pertama, sebenarnya Yesus Kristus dalam telah memberikan contoh bagaimana ia menyebarkan ajaran agama Kristen, dimana yesus kristus tidak menyebarkan ajaran agama Kristen kepada kaum muslim, Hindu, Budha, dan konghucu, melainkan menyebarkan kebada bani israil yang sesat. Sebagaimana terdapat dalam kitab (Matius, 10: 5-9) dan (Matius, 15: 23-24):

Kedua belas rosul kemudian diutus oleh yesus dengan mendapat petunjukpetunjuk ini. Janganlah pergi ke daerah orang-orang bukan Yahudi. Jangan juga ke kota-kota Samaria. Tetapi pergilah kepada orangorang Israel, khususnya kepada mereka yang sesat. Beritahukanlah kepada mereka bahwa Allah akan segera memerintah sebagai Raja. Sembuhkanlah orang-orang sakit, hidupkanlah orangorang yang mati, sembuhkan orang-orang yang berpenyakit kulit yang mengerikan, dan usirlah roh-roh jahat. Kalian sudah menerima semuanya itu dengan cuma-cuma. Jadi, berilah juga dengan Cuma-cuma. Jangan membawa uang ema, uang perak ataupun uang tembaga (Matius, 10-5-9)

Yesus tidak menjawab wanita itu sama sekali. lalu pengikut pengikut Yesus datang kepadanya dan memohon. Pak, suruh wanita itu pergi. Dia hanya ribut-ribut saja di belakang kita. Yesus menjawab, Aku diutus hanya kepada bangsa israel, khususnya pada mereka yang sesat (Matius, 15: 23-24).

Dari ayat suci di atas Nampak jelas bahwa seseorang Kristen tidak diperkenankan melakukan pemaksaan dalam penyebaran agamanya seperti melkukan ancaman terhadap agama lain bahkan sampai dilarang menyeret-nyeret penganut agama lain untuk memasuki agam Kristen.

Yang Kedua, yesus kristus mengajarkan kepada pemeluk agama Kristen untuk bisa hidup damai, rukun dan berdamai baik dengan sesama pemeluk agama Kristen maupun dengan pemeluk agama yang lain. Sebagaimana dijelaskan dalam (Matius. 5: 5-9); Berbahagialah orang-orang yang lembut karena mereka akan

${ }^{15}$ Umbusari dalam Angka 2020 (Jember: BPS Kabupaten Jember)

41| Falasifa, Vol. 12 Nomor 1 Maret 2021 
Mahbub Junaidi

memiliki bumi. Berbahagialah orang-orang yang lapar dan haus akan kebenaran karena mereka akan dipuaskan. Berbahagilah orang yang murah hatinya karena mereka akan beroleh kemurahan. Berbahagilah orang yang suci hatinya karena mereka akan melihat Allah. Berbahgialah orang yang membawa damai karena mereka akan disebut anak Allah.

Yang Ketiga, dalam kitab suci Kristen dijelasakan tentang cinta dan kasih kepada Allah dan kepada sesame manusia. Diman konsep ini adalah konsep yang paling utama dan yang harus di tegakkab didalam agama Kristen. Hal tersebut termaktub dalam (matius, 22: 37-40) Jawab Yesus kepadanya, Kasihilah Tuhan, Allahmu, dengan segenap jiwamu dan segenap akal budimu. Itulah hukum yang terutama dan yang pertama. Dan hukum yang kedua, yang sama dengan itu, ialah kasihilah sesamamu manusia seperti dirimu.

Jadi dari beberapa ayat yang telah disebutkan diatas menunjukkan bahwa ajaran agama Kristen banyak mengajarakan kasih dan dan sayang antar sesama. Hidup yang rukun juga menjadi ajaran penting dalam agama kristen sehingga penganut agama kristen yang taat akan mampu saling menghargai, menghormati, saling percaya, dan tidak saling mencari-cari kejelekan agama lain.

\section{Kerukunan Umat Beragama Perspektif Agama Hindu}

Petama sekali yang harus kita ketahui tentang ajaran agama hindu yaitu agama hindu mempunyai tujuan yang luhu, dimana agama hindu mempunyai tujauan "Moksartham Jagathita Ya ca iti Dharma" artinya mencapai kesejahteraan hidup manusia baik jasmani maupun rohani. Dari tujuan tersebut, maka dalam mencapai kerukunan umat beragama, manusia harus mempunyai dasar hidup "Catur Parusa Artha” yaitub Dharma, Artha, Kama dan Mokhsa. Sebagaimana penjelasan sebagai berikut: 1). Dharma, berarti susila dan berbudi luhur. Kesempuranaan hidup seseorang ditenttukan sejauh mana kulaitas dharma itu sediri. 2). Artha artinya kekayaan. Yakni dengan kekayaan seseorang akan mencapai kebahagian, tetapi harus 
dasari dangen dharma untuk mencapainya. 3). Kama artinya kenikmatan dan kepuasan. Untuk mencapai kepuasa seseorang tentu juga membutuhkan dharma dan artha, dimana dengan sokongan arta ini seseorang akan mendapatkan kepuasan tersendiri dalam hidupnya. 4). Moksha artinya kebahagian abadi, dimana Moksha ini menjadi tujuan akhir dari agama hindu. Mokha ini kalo dalam islam tak ubahnya akhirat dimana manusia seluruhnya akan kembali kepada yang maha kuasa. ${ }^{16}$

Dalam agama Hindu juga sangat kental mengajarkan tentang kerukunan umat beragama sebagaimana dalam dijelaskan statemen dalam Kitab Regweda yang berbunyi "Ekan Sat Vipra Bahuda Vadanti " yang artinya disebut dengan ribuan nama berbeda namun satu adanya. Statemen dalam kitab ini tak ubahnya seperti semboyan Bhinneka Tunggal Ika yang artinya berbeda-beda tapi satu. Jadi sebenarnya ajaran-ajaran dalam agama hindu juga sangat kental dengan kasih sayang, asih dan asuh.

\section{Kerukunan Umat Beragama Perspektif Agama Budha}

Kerukunan umat beragama dalam Agama budha dapat dilihat dari empat konsep kebenaran yakni Dukkha Kebenaran tentang adanya Dukkha, Dukkha Niroda Kebenaran tentang sebab Dukkha, Dukkha Niroda Kebenaran tentang lenyapnya Dukkha, Dukkha Nirodha Gamini Patipada Magga Kebenaran tentang jalan berunsur 8 menuju akhir dukho. Maka dengan tersebut Buddha Gautama memberikan pelayanan terhadap manusia dengan menggunakan dasar-dasar berikut: 1). Keyakinan Tuhan Yang Maha Esa dimana manusia tidak mampu menembus dengan akal pikirannya, 2). Metta, welas asih yang menyeluruh terhadap semua makhluk, 3). Karunia, kasih sayang terhadap sesama makhluk diman hal ini kencendrungan dilakukan meringankan penderitaan mahluk atau manusia, 4). Mudita, yakni perasaan ikut bahagia dengan kebahagian yang didapatkan oleh orang lain. 5). Karma, yakni hukum timbal balik terhadap apa yang dilakukannya, yakni apabila

\footnotetext{
${ }^{16}$ Bashori Mulyono, Ilmu Perbandingan Agama, (Indramayu: Pustaka Sayid Sabiq, 2010), 121-122
} 


\section{Mahbub Junaidi}

berbuat baik maka akan menerima balasan kebaikan dan sebaliknya apabila melakukan keburukan maka akan mendapatkan keburukan. ${ }^{17}$

Dari dasar dasar yang telah disebutkan di atas dapat dikatakan bahwa dalam keyakinan umat agama Buddha, toleransi adalah kerukunan hidup beragama dapat dicapai dengan bertilik tolak kepada knsep dharma. Sementara dalam dharma itu sendiri diajarkan bagaimana cara melaksanakan perbuatan baik, menghindarkan perbuatan jahat, meberikan cinta kasih dan menumbuhkan sikap kerukunan umat beragma.

\section{Kerukunan Umat Beragama Perspektif Agama Konghucu}

Kerukunan Umat Beragama, selain diajarakan oleh agama-agama yang telah disebutkan diatas, juga diajarkan dalam agama Khonghucu. Dimana agama Konghucu ini mengajarkan tentang toleransi yang menjadi prinsip dasar dari ajaran agama Khongucu. Dimana Agama Khonghucu ini agama baru yang diresmikan Gussur di Indonesia, Agama Konghucu ini juga mengajarkan toleransi, dimana menjadi prinsip dasar dari ajaran Agama Khongucu sebgaimana di sebutkan dalam Kitab (Tengah Sempurna, XII: 3) "jangan lakukan kepada orang lain apa yang tidak ingin engkau terima oleh orang lain". Selain itu, dinyatakan dan dipertegas oleh Nabi Konghucu bahwa "Seorang budiman berhati longgar dan lapang, seorang rendah budi berhati sempit dan berbelit" hal ini di sebutkan dalam Sabda Suci, VII: 37. Jadi bisa dilhat agama yang baru diresmikan di indenesia pun juga mempunyai prinsipprinsip tentang kerukunan antar umat beragama. Sehingga padaha hakikatnya setia agama agama yang ada di Indonesia pada subtansinya mengajarkan nila-nilai kerukunan dan harmunisasi antar umat beragama.

Selain dari sabda suci di atas, dalam sabda suci yang lain juga menegaskan tentang ajaran kerukunan umat beragama yang berbunyi "seorang budiman menjunjung tiga syarat di dalam jalan suci. Di dalam sikap dan lakunya, ia

\footnotetext{
${ }^{17}$ Bashori Mulyono, Ilmu Perbandingan Agama, , 123-124
} 
menjauhkan sikap congkak dan angkuh, pada wajahnya selalu menunjukkan sikap dapat dipercaya dan di dalam percakapan selalu ramah serta menjauhi kata kasar" (Sabda Suci, VIII: 43) dan juga dijelaskan dalam sabda suci juga yang berbunyi “ditempat penjuru lautan, semuanya bersaudara" (Sabda Suci, XII: 5). Dari sini dapat dilihat keseriusan dan kesungguhan agama Konghucu dalam menjaga kerukunan antar umat beragama.

\section{Peran Penyuluh Agama Terhadap Kerukunan Antar Umat Beragama}

\section{Pengertian penyuluh agama}

Penyuluh menurut Slameto sebagaimana dikutip M. Ummar dan Sartono dalam bukunya bahwa, Penyuluhan adalah salah satu teknik memberikan bimbingan. Penyuluhan merupakan inti dari bimbingan. ${ }^{18}$ Penyuluhan dilakukan untuk membantu mengatasi masalah-masalah sosial, spiritual dan moral. Penyuluh agama berarti orange yang memberikan penyuluhan dan bimbingan kepda masyarakat terkait dengan wawasan dan pengetahuan keagamaan. Menurut Dr. H. Noor Fahmi, MM Penyuluh agama adalah pegawai negeri sipil maupun honorer yang diberi tugas, tanggung jawab dan wewenang untuk melakukan bimbingan dan penyuluhan agama dengan menggunakan bahasa agama. Penyuluh agama adalah juru penerang bagi masyarakat dengan menyampaikan prinsip-prinsip, etika dan nilai keberagamaan yang baik. ${ }^{19}$

Penyuluh agama terdiri dari penyuluh agama islam, Kristen katolik, protestan, Hindu, Budha dan Konghucu, tetapi penulis disini fokus membahas tentang penyuluh agama islam sebagai agama mayoritas san terbesar di Indonesia. penyuluh agama islam ini ada yang pegawai negeri sipil (PNS) ada yang honorer (Non-PNS) dimana dari masing-masing penyuluh ini mempunyai tanggung jwab dan fungsing masing masing dengan spesialisasinya pemberantas buta aksara, keluarga sakinah, pengelolaan zakat, pemberdayaan wakaf, produk halal, kerukunan umat beragama,

\footnotetext{
${ }^{18}$ Umar \& Sartono, Bimbingan Penyuluhan (Bandung : Pustaka Setia, 1998), 15

${ }^{19}$ Subbag Inmas Kanwil Kalsel, Penyuluh Agama Juru Penerang (Kalsel: Catur Wulan 2017),06
} 
radikalisme dan aliran sempalan, penyalahgunaan naorkoba dan penanggulangan HIV/AID.

\section{Tugas Dan Fungsi Penyuluh Agama Terhadap Kerukunan Umat Beragama}

Peranan penyuluh agama di sukoreno diemban oleh penyuluh dengan spesialisasi "Kerukunan Umat Bergama". Penyuluh agama dengan spesialisasi ini setidaknya mampu memahami alasan pentingnya kerukunan antar umat beragama, memahami pengertian kerukunan antar umat beragama, mengetahui landasan teologis tentang kerukunan antar umat beragama baik dari al-Quran, hadits, dan pendapat para ulama, mengetahui regulasi pengaturan kehidupan antar umat beragama, memiliki wawasan tentang realitas agama-agama dan aliran kepercayaan di lingkungan masyarakat Indonesia.

Sedangkan Tugas Dan Fungsi Penyuluh Agama Terhadap Kerukunan Umat Beragama yaitu sebagai fungsi Informatif/Edukatif, Konsultatif, dan advokatif:

\section{a. Fungsi informatif/edukatif}

Penyuluh agama memberikan informasi atau pengajaran teertkait kerukunan umat beragama, yang meliputi pengertian kerukunan, umat, ukhuwah, dan lain sebagainya. Termasuk memberikan penjelasan dengan beberapa konflikkonflik yang terjadi dengan faktor-faktor penyebab terjadinya konflik. Penyuluh agama memberikan edukasi kepada masyarakat bahwa kerukunan umat beragama merupakan sesuatu hal yang penting untuk dipahami untuk dijalankan dalam kehidupan sosial melihat negara indonesi adalah negara yang majemuk berbeda suku, ras, agama, dan budaya.

\section{b. Fungsi Konsultatif}

Penyuluh agama menerima konsultasi atau pengaduanpengaduan dari masyarakat berkenaan dengan masalah kerukunan agama yang terjadi di 
lingkungan mereka. Seperti ketika terjadinya konflik beragama atau hal lain yang mengganggu kerukunan umat beragama.

\section{c. Fungsi Advokatif}

Penyuluh agama membantu meredakan, mengatasi, dan menyelesaikan masalah-masalah kerukunan beragama yang terjadi di masyarakat, baik yang bersifat intern umat beragama maupun yang bersifat ekstern umat beragama. ${ }^{20}$

\section{KESEMPULAN}

Kerukunan umat beragama adalah keadaan hubungan sesama umat beragama yang dilandasi toleransi, saling pengertian, saling menghormati, menghargai kesetaraan dalam pengamalan ajaran agamanya dan kerjasama dalam kehidupan bermasyarakat, berbangsa dan bernegara di dalam Negara Kesatuan Republik Indonesia berdasarkan Pancasila dan Undang-Undang Dasar Negara Republik Indonesia Tahun 1945. Masyarakat Di desa Sukerone kecamatan Umbulsari adalah masyarakat yang majemuk dimana terdiri dari dari banyak etnis, budaya, tradisi bahkan tradisi yang berbeda. Tetepi sikap saling menghormati, memberikan kebebasan beragama, menerima agama lain dengan lapang dada, dan selalu saling berfikri positif antar pemeluk agama.

Dari sekian agama yang ada di Indonesia erat kaitannya dengan pengajaran kerukunan antar sesama dan antar umat Bergama baik dalam agama Islam, Kristen Katolik Kristen Protestan, Hindu, Budha dan Konghunghucu. Tak memandang agama orang lain berbeda dengan keyakinan agamanya tetapi sama sama saling menghormati, hal itu bisa di dapatkan dari masing-masing ajaran agama agama yang terkandung dalam kitab sucinya.

Penyuluh agama adalah orang yang dibentuk oleh pemerintah kementrian agama untuk memberikan penyuluhan dan bimbingan kepda masyarakat terkait dengan wawasan dan pengetahuan keagamaan. Penyuluh agama mempunyai fungsi edukatif/informatif, fungsi konsultatif dan fungsi advokatif. Dimana penyuluh di sukoreno Umbulsari terus

\footnotetext{
${ }^{20}$ Bimas Islam Kemenag RI. Modul pelaksanaan Tugas Penyuluh Agama Islam (Jakarta: Ditjen Bimas Islam Kemenag RI 2019), 158
}

47 | Falasifa, Vol. 12 Nomor 1 Maret 2021 
Mahbub Junaidi

melakukan tugasnya mulai dari melakukan penyuluhan sampai mengadvokasi permasalahan-permasalahan keberagamaan upaya meningkatkan kualitas kerukunan antar umat beragama.

\section{DAFTAR PUSTAKA}

Bashori Mulyono, Ilmu Perbandingan Agama, (Indramayu: Pustaka Sayid Sabiq, 2010)

Bimas Islam Kemenag RI. Modul pelaksanaan Tugas Penyuluh Agama Islam (Jakarta: Ditjen Bimas Islam Kemenag RI 2019)

Depag RI. Bingkai Teologi Kerukunan Hidup Umat Beragama Di Indonesia,(Jakarta: Badan Penelitian dan pengembangan Agama Proyek Peningkatan KUB di Indonesia. 1997)

Dewan Ensiklopde American, Ensiklopedi American

Dewan Ensiklopedi Indonesia, Ensiklopedia Indonesia Jilid 6,(Van Hoeve,t,th)

H. Said Agil Husain Al Munawar. Fikih Hubungan Antar Agama(Jakarta,Ciputat Press. 2003)

Hamzah Tualeka Zn. Sosiologi Agama (Surabaya: UINSA Press, 2011)

Joachim Wach, The Comparative Study of Religions (New York: Columbia University Press, 1958)

Ridwan Lubis. Cetak Biru Peran Agama (Jakarta, Puslitbang, 2005)

Saidurrahman dan Arifinsyah. Nalar Kerukunan: Merawat Keragaman Bangsa Mengawal NKRI (Jakarta: PT. Prenadamedia Group, 2018)

Subbag Inmas Kanwil Kalsel, Penyuluh Agama Juru Penerang (Kalsel: Catur Wulan 2017)

Syahrin Harahap, Teologi Kerukunan, (Jakarta: Prenada Media Group, 2011), 58

Umar \& Sartono, Bimbingan Penyuluhan (Bandung : Pustaka Setia, 1998)

Umbusari dalam Angka 2020 (Jember: BPS Kabupaten Jember)

W.J.S Porwadarminta, kamus Umum Bahasa Indonesia(Jakarta, Balai Pustaka1986)

Falasifa, Vol. 12 Nomor 1 Maret 2021 | 48 
https://islam.nu.or.id/post/read/75972/tafsir-ayat--tidak-ada-pemaksaan-memelukislam-di akses pada tanggal 10 Desember 2020 Jam 09.00WIB 